\title{
UPAYA GURU DALAM PENINGKATAN KETERAMPILAN MOTORIK HALUS MELALUI KEGIATAN MELIPAT KERTAS PADA ANAK USIA DINI DI RA SYARQUL AUSAT GUNUNG HALU
}

\author{
Neng Haniah \\ IKIP SILIWANGI BANDUNG \\ Nenghaniah1985@gmail.com
}

\begin{abstract}
In this study, researchers chose a place of research in a Raudhatul Athfal (RA) institution in the Gununghalu sub-district of West Bandung Regency, namely in RA Syarqul Ausat Gununghalu. In this institution researchers still find common problems of early childhood education that can occur in educational institutions anywhere. The general problem is in the form of fine motor skills that are still difficult to apply to early childhood educators. That is why they are not enthusiastic about developing fine motor skills. One of the learning activities that can improve fine motor skills is folding paper. This study uses a descriptive research method with a qualitative approach. In this case the researcher only explains or describes a situation or fact in the field without the need to analyze the interrelationship between variables. The stages in this study include several steps, namely the planning stage, implementation phase, and evaluation stage. Based on the results of the previous analysis and discussion, the researcher can conclude that the teacher in an effort to improve Fine Motor Skills Through the Activity of Folding Paper in Early Childhood in RA Syarqul Ausat Gununhalu is good. This can be seen from the acquisition of the number of acquisition scores from the results of the evaluation of early childhood as many as 1247 with an average number of 83 classified as good
\end{abstract}

\begin{abstract}
Abstrak
Dalam penelitian ini, peneliti memilih tempat penelitian di suatu lembaga Raudhatul Athfal (RA) di wilayah kecamatan Gununghalu Kabupaten Bandung Barat yaitu di RA Syarqul Ausat Gununghalu. Di lembaga tersebut peneliti masih menemukan permasalahan umum pendidikan anak usia dini yang bisa terjadi pada lembaga pendidikan di manapun. Permasalahan umum tersebut yaitu berupa adanya keterampilan motorik halus yang masih sulit untuk diterapkan pendidik terhadap anak usia dini. Hal itulah yang menyebabkan mereka tidak antusias dalam kegiatan pengembangan keterampilan motorik halus. Salah satu kegiatan pembelajaran yang dapat meningkatkan keterampilan motorik halus yaitu melipat kertas. Penelitian ini menggunakan metode penelitian deskriptif dengan pendekatan kualitatif. Dalam hal ini peneliti hanya menjelaskan atau menggambarkan suatu keadaan atau fakta dilapangan tanpa perlu menganalisis keterkaitan antar variabel. Adapun tahapan dalam penelitian ini meliputi beberapa langkah yaitu tahap perencanaan, tahap pelaksanaan, dan tahap evaluasi. Berdasarkan hasil analisis dan pembahasan sebelumnya, maka peneliti dapat simpulkan bahwa guru dalam upaya meningkatkan Keterampilan Motorik Halus Melalui Kegiatan Melipat Kertas Pada Anak Usia Dini di RA Syarqul Ausat Gununhalu adalah baik. Hal tersebut dapat dilihat dari perolehan jumah skor perolehan dari hasil evaluasi anak usia dini yaitu sebanyak 1247 dengan jumlah rata-rata sebesar 83 yang tergolong kategori baik.
\end{abstract}

Kata kunci: Motorik Halus, Melipat Kertas. 


\section{PENDAHULUAN}

Anak usia dini adalah bagian dari suatu piha yang penting dalam menyumbangkan kemajuan bagi suatu bangsa dan negara, karena anak usia dini merupakan generasi penerus yang akan mengisi kehidupan yang akan berlangsung di masa yang mendatang. Kemajuan generasi suatu bangsa ditentukan dengan pertamakali meningkatkan suatu potensi berupa keterampilan-keterampilan yang ada pada diri anak usia dini. Hal tersebut dilakukan dengan menentukan aspek-aspek perkembangan anak. Aspek-aspek yang ada pada anak meliputi aspek perkembangan bahasa, kognitif, nilai agama dan moral, fisik motorik, dan sosial emosional.

Dalam perkembangannya, seorang anak mempunyai potensi yang besar untuk menentukan keberhasilan dimasa depan. Dalam proses kegiatan pembelajaran, aspek yang paling berpengaruh pada perkembangan anak adalah aspek motorik.Selain dari pada itu, dalam proses kegiatan pembelajaran, anak memiliki karakteristik atau sifat yang berbeda-beda. Karakteristik tersebut diantaranya adalah memiliki rasa keingin tahuan yang besar, memilikipribadi yang unik, berpikir konkrit, senang berfantasi dan berimajinasi, aktif dan energik, berjiwa petualang, belajar dengan menggunakan tubuh, adanya daya kosentrasi, bagian dari makhluk sosial, spontan, dan sebagainya.

Proses pengembangan potensi atau keterampilan yang ada dalam diri seorang anak bisa didapat melaluisuatu pembelajaran di lembaga-lembaga formal, seperti TK, Kober, RA dan sebagainya. Dilembaga-lembaga tersebut, biasanya anak usia dini dikelompokan berdasarkan umur. Kelompok pertama adalah anak kelompok usia 4 sampai 5 tahun yang dikategorikan kelompok A kemudian yang kedua adalah kelompok anak usia 5 sampai 6 tahun yang dikategorikan sebagai kelompok B.Dalam melakukan suatu proses kegiatan baik kegiatan bermain maupun kegiatan pembelajaran, anak memerlukan tenaga untuk mengembangkan motorik kasar ataupun motorik halusnya.

Dalam melakukan proses penelitian, peneliti memilih tempat penelitian di suatu lembaga
Raudhatul Athfal (RA) di wilayah kecamatan Gununghalu Kabupaten Bandung Barat yaitu di RA Syarqul Ausat yang berada di anak usia dini merupakan generasi penerus yang akan mengisi kehidupan yang akan berlangsung di masa yang mendatang. Kemajuan generasi suatu bangsa ditentukan dengan pertamakali daerah Gununghalu. Keberhasilan lembaga tersebut adalah adanya kemampuan untuk dapat menciptakan sebuah suasana pembelajaran yang sangat menyenangkan sehingga anak usia dini mampu meningkatkan suatu keterampilan motorik dengan baik. Keberhasilan tersebut tercipta karena dorongan maupun kesadaran dari pendidik itu sendiri akan pentingnya suasana pembelajaran dan kegiatan yang menyenangkan. Meski demikian, peneliti masih menemukan permasalahan umum yang ada di suatu lembaga pendidikan pembelajaran anak yang bisa terjadi pada lembaga pendidikan di manapun. Permasalahn umum tersebut yaitu sulitnya seorang pendidik dalam menerapkan dan mengembangkan suatu keterampilan berupa motorik halus seperti melipat kertas. Dalam kegiatan tersebut anak selalu meminta bantuan kepada guru untuk melakukan melipat kertas. Jumlah lipatan sudah sesuai standar yang terdapat dalam indikator pengembangan kegiatan meniru bentuk yaitu 1-7 lipatan. Tetapi kenyataannya sebagian besar anak tidak bisa melakukan lipatan sampai ditahap akhir, mereka merasa kesulitan melipat kertas. Dengan hal-hal seperti itulah yang menyebabkan kurangnya perkembangan motorik yang terdapat pada diri anak usia dini.

Dengan demikin, maka diperlukan sebuah upaya untuk meningkatkan keterampilan motorik anak. Peningkatan keterampilan motorik dapat dilakukan dengan cara melakukan kegiatan pembelajaran yang sesuai. Salah satu contohnya adalah dengan melaksanakan kegiatan pemebelajaran melipat kertas..

Kegiatan pembelajaran melipat kertas sangat berpengaruh dalam melatih kesinambungan antara mata dan otot-otot tangan serta konsentrasi anak. Memiliki keterampilan dalam suatu proses melipat kertas bisa menjadi modal awal anak sebagai bekalnya nanti dalam mengurus dirinya 
sendiri. Berawal dari kegiatan pembelajaran melipat kertas akan dapat membantu anak untuk bisa melipat bajunya sendiri, ataupan melipat benda-benda yang mudah untuk dilipat. Selain itu kegiatan melipat ketas juga dapat meningkatkan suatu kemampuan anak dalam mengenal bentuk, dari kertas yang telah melalui proses lipatanbisa menjadi bentuk benda.

Misalnya bentuk baju, perahu, bunga, dan masih banyak contoh-contoh yang lain dalam bentuk yang berbeda-beda. Kegiatan pembelajaran melipat kertas akan membuat anak tertarik untuk latihan melipat kertas. Hasil dari lipatan itu dapat dipakai untuk mainan anak. Dari runtutan alasan di atas maka penulis mengambil judul upaya guru dalam peningkatan keterampilan motorik halus dengan melalui suatu kegiatan melipat kertas pada anak usia dini di RA Syarqul Ausat Gununghalu.

\section{KAJIAN TEORI}

Perkembangan motorik adalah suatu proses untuk tumbuh kembangnya suatu kemampuan gerakanseorang anak. Pada dasarnya, perkembangan motorik adalah perkembangan yang selaras dengan kematangan syaraf dan otototot anak. Syaraf dan otot-otot kecil anak digunakan pada saat melakukan interaksi yang begitu kompleks dari bagian atau sistem yang ada di dalam tubuh yang kemudian dikontrol langsung oleh otak. Pekembangan motorik merupakan perkembangan yangberkaitan dengan gerak jasmani yang terkoordinasi oleh syaraf pusat, urat syaraf dan otot.

Anak usia dini dapat mengembangkan suatu kemampuan yang berkaitan dengan keterampilan motorik halus jiga ia mendapatkan rangsangan dengan optimal. Disetiap tahap, seorang anak sangat membutuhkan rangsangan. Dengan mendapatkan berbagai hal dari suatu proses penglihatan dan pendengaran, anak akan meningkatkan suatu kemampuaketerampilan berupa motorik halus dengan optimal. Tetapi sebaliknya, jika seorang anak kurang mendapatkan rangsangan maka anak tersebut akan merasa begitu bosan.Tetapi dalam hal ini, anak tidak boleh terlalu sering diberikan rangsangan atau tekanan secara terus-terusan karena akan menimbiulkan hal yang negatif bagi perkembangan mtorik atau perkembangan yang lainnya.

Menurut Sujiono motorik halus merupakan pergerakan bagian-bagian tubuh tertentu saja yang dilakukan dapat dengan otot-otot kecil.Maka oleh itu pergerakan ini tidak terlalu membutuhkan tenaga yang besar hanya yang dibutuhkan adalah kecermatan dan koordinasi mata dengan tangan(Ahmad Syukri Sitorus, 2016). Kemudian dalam pengertian lain keterampilan motorik halus adalah aktivitas yang memerlukan pemakaian otot-otot kecil pada tangan(Koenarso, 2017). Sementara itu, keterangan lain mengatakan bahwa motorik halus adalah sebuah pergerakan yang dilakukan oleh anggota tubuh anak yang menggunakan beberapa otot-otot halus yang dipengaruhi oleh sebuah kesempatan berlatih dan belajar.(Setiyowati, 2015). Kemudian menurut Decaprio kegiatan pembelajaran motorik halus merupakan suatu kegiatan yang melibatkan otot-otot kecil serta adanya sebuah koordinasi mata serta tangan(Decaprio, 2013).

Arti melipat atau yang disebut denganorigami jugadijelaskan oleh salah satu ahli(Sumanto, 2005)yang mengatakan bahwa melipat adalah karya seni yang pada umumnya memakai bahan kertas yang memiliki tujuan untuk menciptakan beraneka ragam bentuk dan hiasan. Bagi anak usia dini, melipat kertas adalah hal yang sangat menyenangkan. Hal itu dikatakan karena melipat kertas dapat disusun dengan tujuan membentuk suatu hiasan atau bentuk yang diinginkan. Hal itulah yang menjadikan kegiatan melipat kertas sebagai kegiatan yang dapat meningkatkan suatu keterampilan berupa motorik halus pada anak usia dini.

Selin itu, kegiatan melipat juga memiliki tujuan untuk melatih kemampuan daya ingat, pengamatan, keterampilan tangan, mengembangkan daya fantasi, kreasi, ketelitian, kerapian, dan perasaan keindahan.

Melipat dapat dilakukan dengan cara mengubah lembaran kertas berbentuk bujursangkar, empat persegi, atausegi tiga menurut arah ataupun ke dalam pola pola tertentu sehingga tercipta sebuah bentuk lipatan yang diinginkan. 


\section{JURNAL CERIA}

ISSN : 2614-6347 (Print) 2614-4107 (Online)

Vol.1 1 No.6 1 November 2018

Dalam pelaksanaan kegiatan melipat kertas, tentunya harus mengikuti acuan atau rujukan sebagai dasar-dasar melipat. Hal ini dilakukan supaya anak usia dini akan lebih mudah dalam melakukan proses melipat. Dasar-dasar melipat (Sumanto, 2005) adalah:

Pertama, gunakan kertas yang diperuntukan khusus untuk melipat. Kertas lipat biasa memiliki ukuran yang kecil dengan memiliki berbagai macam warna. Selain itu, berbagai kertas lainnya juga bisa digunakan untuk melakukan kegiatan melipat seperti kertas HVS, kertas koran, kertas sukung/marmer, kertas payung, kertas buku tulis, dan sejenisnya.

Kedua, Setiap model lipatan, ada yang dibuat dengan menggunakan kertas yang berbentuk bujur sangkar, bujur sangkar ganda, empat persegi panjang, dan segi tiga. Dengan menggunnakan model yang ditentukan, maka dalam proses melipat kertas akan terlaksana dengan mudah dan sesuai keinginan.

Ketiga, mengikuti pentunjuk atau arah yang terdapat pada gambar. Hal ini harus dilakukan supaya dalam pembuatannya anak usia dini tidak keliru. Anak pada usia dini harus mengikuti petunjuk arah dalam gambar atau dalam buku orgami dari awal sampai akhir.Keempat, kualitas dari hasil melipat kertas yang dilakukan, diperoleh berdasarkan ketelitian anak dalam melakukannya dari awal sampai akhir.

Menurut(Sumanto, 2005)langkah-langkah kerja dalam melipat yaitu pertama adalah tahap persiapatan, yaitu dengan menentukan berbagai bentuk, warna, dan ukuran dari kertas yang dipakai untuk melipat. Persiapkan bahan pembantudanalat yangdiperlukansesuai model yang akan dibuat. Setelah itu, Tahap pelaksanaan, ialah dengan melakukan proses lipatan-lipatan kertas membentuk menjadi suatu objek tanpa keluar dari dari dasar-dasar melipat kertas dari awal sampai akhir. Selanjutnya adalah tahap penyelesaian, ialah dengan melengkapi bagianbagian tertentu.

\section{METODE}

Metode yang digunakan dalam penelitian ini adalah metode deskriptif dengan pendekatan kualitatif. Penelitian deskriptif ialah penelitian yang memiliki tujuan untuk untuk menggambarkan secara sistematis, akurat, dan faktual mengenai fakta dan sifat populasi tertentu(Sanjaya, 2015). peneliti hanya menjelaskan atau menggambarkan suatu keadaan atau fakta dilapangan tanpa perlu menganalisis keterkaitan antar variabel.

Penelitian ini dilakukan dengan tiga tahapan yakni tahap perencanaan pembelajaran, tahap pelaksanaan pembelajaran, dan tahap evaluasi pembelajaran. Dalam suatu tahap perencanaan kegiatan pembelajaran, guru membuat beberapa program perencanaan pelaksaan pembelajaran dalam bentuk Rencana Pelaksanaan Pembelajaran Harian (RPPH). Berikut pembahasan RPPH yang dibuat oleh pendidik sebelum proses pelaksanaan pembelajaran berlangsung.

\section{HASIL DAN PEMBAHASAN \\ HASIL}

Dalam penyusunan Rencana Pelaksanaan Pembelajaran Harian (RPPH), pertama guru mencantumkan identitas lembaga berupa nama lembaga, semester, hari dan tanggal serta kelompok anak yang ada di lembaga tersebut. Setelah mencantumkan identitas lembaga, guru menuliskan Kompetensi Dasar (KD), metode pembelajaran, materi pembelajaran, serta bahan yang digunakan. Setelah menetapkan suatu bahan pembelajaran, barulah guru merencanakan langkah-langkah pembelajaran. Langkah-langkah pembelajaran yang diterapkan guru terdiri atas tiga kegiatan yaitu kegiatan pembukaan, kegiatan inti, dan kegiatan penutupan.

Kemudian, dalam melakukan tahap pelaksanaan pembelajaran peneliti dapat melihat dari hasil observasi dan studi dokumentasi, penulis mendapatkan data bahwa guru RA Syarqul Ausat dalam melakuka peningkatansuatu kemampuan keterampilan motorik halus dengan melalui kegiatan melipat kertas menggunakan beberapa upaya pembelajaran yang sesuai dengan RPPH yang telah dibuat pada tahap perencanaan pembelajaran.

Selanjutnya, dalam prosespelaksanaan evaluasi dan penilaian hasil karya anak usia dini, guru menggunakan tiga kategori yaitu ketangkasan, kerapihan, dan mengikuti petunjuk guru.Untuk menentukan nilai akhir dari hasil karya anak pada 


\section{JURNAL CERIA}

ISSN : 2614-6347 (Print) 2614-4107 (Online)

Vol.1 No.6 1 November 2018

usia dini, guru menggunakan rumus nilai akhir sebagai berikut.

\section{Nilai Akhir $=\underline{\text { Jumlah Skor } \mathrm{x} 100}$ Skor Maksimal}

Setelah merumuskan untuk menentukan nilai kahir, guru juga menentukan tolok ukur untuk menentukan hasil harya tergolong sangat baik, baik, dan kurang baik. Berikut adalah tolok ukur yang digunakan.

\begin{tabular}{|c|c|c|}
\hline No & Interval Nilai & $\begin{array}{c}\text { Tingkat } \\
\text { Kemampuan }\end{array}$ \\
\hline 1 & $86-100$ & Sangat Baik (SB) \\
\hline 2 & $71-85$ & Baik (B) \\
\hline 3 & $51-65$ & Kurang (K) \\
\hline 4 & $0-50$ & Kurang Sekali (KS) \\
\hline
\end{tabular}

Berdasarkan hasil observasi dan studi dokumentasi, hasil akhir dari evaluasi terhadap hasil karya anak usia dini adalah sebagai berikut.

\begin{tabular}{|c|l|c|c|c|c|c|c|}
\hline \multirow{2}{*}{ No } & \multirow{2}{*}{ Siswa } & \multicolumn{2}{|c|}{ Aspek Penilaian } & & & Keta \\
\cline { 3 - 7 } & & $\begin{array}{c}\text { Kera } \\
\text { kasa } \\
\text { n } \\
\text { piha } \\
\text { n }\end{array}$ & $\begin{array}{c}\text { Sesu } \\
\text { ai } \\
\text { petu } \\
\text { njuk }\end{array}$ & $\begin{array}{c}\text { Jml. } \\
\text { Skor }\end{array}$ & Nilai & $\begin{array}{c}\text { Kema } \\
\text { mpuan }\end{array}$ \\
\hline 1 & Aulia A & 3 & 2 & 3 & $\mathbf{8}$ & $\mathbf{8 9}$ & SB \\
\hline 2 & Anggun A & 2 & 2 & 3 & $\mathbf{7}$ & $\mathbf{7 8}$ & B \\
\hline 3 & Apdal A & 2 & 2 & 3 & $\mathbf{7}$ & $\mathbf{7 8}$ & B \\
\hline 4 & Ila Nur L & 2 & 2 & 2 & $\mathbf{6}$ & $\mathbf{6 7}$ & K \\
\hline 5 & M Pajri & 3 & 2 & 3 & $\mathbf{8}$ & $\mathbf{8 9}$ & SB \\
\hline 6 & M Reza & 3 & 3 & 3 & $\mathbf{9}$ & $\mathbf{1 0 0}$ & SB \\
\hline 7 & Nabila A & 2 & 2 & 3 & $\mathbf{7}$ & $\mathbf{7 8}$ & B \\
\hline 8 & Naura A & 3 & 2 & 2 & $\mathbf{7}$ & $\mathbf{7 8}$ & B \\
\hline 9 & Pahira A & 3 & 3 & 3 & $\mathbf{9}$ & $\mathbf{1 0 0}$ & SB \\
\hline 10 & Regina & 3 & 2 & 3 & $\mathbf{8}$ & $\mathbf{8 9}$ & SB \\
\hline 11 & Reksa R & 3 & 3 & 3 & $\mathbf{9}$ & $\mathbf{1 0 0}$ & SB \\
\hline
\end{tabular}

\begin{tabular}{|l|l|c|c|c|c|c|c|}
\hline 12 & Sahad S & 3 & 2 & 3 & $\mathbf{8}$ & $\mathbf{8 9}$ & SB \\
\hline 13 & Salsa & 2 & 2 & 3 & $\mathbf{7}$ & $\mathbf{7 8}$ & B \\
\hline 14 & $\begin{array}{l}\text { Siti } \\
\text { Amelia }\end{array}$ & 2 & 2 & 3 & $\mathbf{7}$ & $\mathbf{7 8}$ & $\mathbf{B}$ \\
\hline 15 & Yulia & 2 & 1 & 2 & $\mathbf{5}$ & $\mathbf{5 6}$ & K \\
\hline Jumlah & $\mathbf{3 7}$ & $\mathbf{3 2}$ & $\mathbf{4 2}$ & $\mathbf{1 1 2}$ & $\mathbf{1 2 4 7}$ & \\
\cline { 1 - 1 } \multicolumn{2}{l|l}{ Rata-rata } & 2.5 & 2.1 & 2.8 & 7.5 & $\mathbf{8 3}$ & \\
\hline
\end{tabular}

\section{PEMBAHASAN}

Dari data yang didapatkan, dapat ditarik kesimpulan bahwa upaya guru dalam mengembangakan keterampilan motorik anak usia dini cukup baik. Dengan penggunaan metode, kegiatan yang dipilih, serta langkahlangkah pembelajaran yang telah dilakukan oleh pendidik dapat menjadikan anak lebih antusias dalam melakukan pembelajaran, sehingga dalam perkembanganketerampilan berupa motorik halus yang dimiliki anak usia dini dapat berkembang dengan cukup baik. Hal tersebut dilihat dari hasil rata-rata nilai seluruh anak usia dini yaitu sebesar 83 yang tergolong baik.

\section{KESIMPULAN}

Berdasarkan hasil deskripsi penelitian, upaya guru dalam peningkatan suatu keterampilan motorik halus dilaksanakan melalui kegiatan melipat kertas dengan menempuh proses atau langkah-langkah yang baik. Upaya peningkatan keterampilan motorik halus dilakukan oleh guru dengan tiga tahapan yaitu proses perencanaan, pelaksanaan dan evaluasi. Dalam melakukan pelaksanaan proses pembelajaran, guru mencoba membuat anak melakukan kegiatan melipat kertas dalam bentuk ikan. Kegiatan pembelajaran ini dilakukan dengan menerapkan suatu metode yang cukup efektif yaitu metode demonstrasi, yaitu guru memperagakan bagaimana langkah-langkah atau cara-cara dalam melakukan kegiatan melipat kertas.

Berdasarkan hasil analisis dan pembahasan sebelumnya, maka peneliti dapat simpulkan bahwa guru dalam upaya peningkatan suatuberupa keterampilan motorik halus melalui 


\section{JURNAL CERIA}

ISSN : 2614-6347 (Print) 2614-4107 (Online)

kegiatan melipat kertas pada anak usia dini ini di RA Syarqul Ausat Gununghalu melalui upaya sebagai berikut:

1. Pada tahap perencanaan, guru menyusun berbagai program pelaksanaan pembelajaran seperti penyusunan program tahunan, program semester, RKM, RKH dan RPPH.

2. Pada tahap pelaksanaan pembelajaran, guru melakukan langkah-langkah sesuai dengan yang tersusun di dalam RPPH dengan menggunakan metode pembelajaran demonstrasi yang efektif.

3. Pada tahap evaluasi pembelajaran, anak usia dini diarahkan untuk membuat origami dalam bentuk ikan. Anak usia dini memperoleh hasil penilaian yang baik. Hal tersebut dapat dilihat dari perolehan jumah skor perolehan dari hasil evaluasi anak usia dini yaitu sebanyak 1247 dengan jumlah rata-rata sebesar 83 yang tergolong kategori baik

\section{DAFTAR PUSTAKA}

Ahmad Syukri Sitorus. (2016). Perkembangan
Motorik Halus Pada Anak Usia Dinie, IV(2), 2339.

Decaprio, R. (2013). Aplikasi teori pembelajaran motorik di sekolah. Jogjakarta: DIVA Press (Anggota IKAPI).

Koenarso, D. A. P. (2017). Penerapan melipat, menggunting, menempel (3m) dalam upaya meningkatkan keterampilan motorik halus anak, 3(1), 1-8.

Sanjaya, W. (2015). Penelitian pendidikan.

Kakarta: Prenada Media.

Setiyowati, N. (2015). Analisis Kebutuhan

Perkembangan Fisik Motorik Halus Melalui

Penerapan Kegiatan Kolase Di Ra Al-

Mutsnawiatul Islam Kelompok a Mlarak

Ponorogo. In Prosiding Seminar Nasional

Pendidikan "Meretas Sukses Publikasi

Ilmiah Bidang Pendidikan Jurnal

Bereputasi” (pp. 117-120).

Sumanto. (2005). Pengembangan Kreativitas

Senirupa Anak TK. Jakarta: Departemen Pendidikan Nasional. 